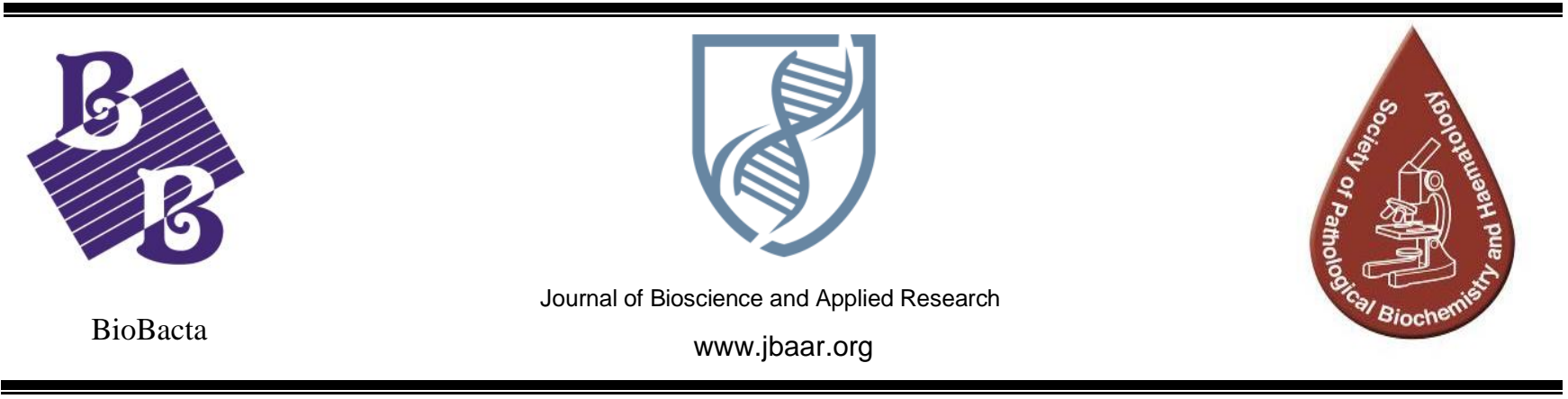

\title{
Gelatin-coated magnetic nanoparticles-based DNA isolation method: A comparison with commercial DNA isolation kits from whole blood
}

\author{
Kelly S Levano ${ }^{1,2}$, Luis Jaramillo-Valverde ${ }^{1,2}$, Elizabeth Delgado $^{1,2}$, Heinner Guio $^{1,2 *}$ \\ ${ }^{1}$ INBIOMEDIC Research and Technological Center, Lima, Peru; \\ ${ }^{2}$ ALBIOTEC, Lima, Peru; \\ *Correspondence: Heinner Guio, PhD, E-mail: heinnerguio@gmail.com \\ Received date: January 15, 2019. Accepted: March 25, 2019, Published: March 29, 2019
}

\begin{abstract}
DNA isolation is the first step for most molecular tests, thus indicating the importance of using a reliable and suitable method for this procedure. The use of magnetic nanoparticles for blood DNA isolation offers several advantages including subjecting little mechanical stress to your sample, obtaining higher quality and quantity of DNA, and non-laborious procedures. In this study, we isolated genomic DNA using gelatin-coated magnetic nanoparticles from blood samples and test its use compare with three commercial blood DNA isolation kits. DNA purity and yield were assessed by measuring absorbance at A260/A280 and by agarose gel electrophoresis. The suitability of the isolated DNA for downstream applications was analyzed by endpoint PCR and Sanger sequencing. In this study, gelatin-coated magnetite particles for genomic DNA isolation provide an efficient, simple, and inexpensive method that does not require the use of commercial blood DNA Isolation Kit.
\end{abstract}

DOI: 10.21608/JBAAR.2019.138335

Keywords: Blood, DNA isolation, Magnetic nanoparticles, PCR

\section{INTRODUCTION}

An appropriate DNA isolation method for a specific biological sample (whole blood, saliva, stool, urine, fresh tissue, or paraffin-embedded tissue) is a prerequisite for any molecular testing. This selection is dependent on many factors including yield, purity, time, safety, specialized equipment requirement, trained personnel, intended downstream applications, cost, and sample source.

Blood is an ideal source of human genomic DNA (Cho et al., 2007). However, isolating genomic DNA by traditional methods is a time-consuming process, and phenol and chloroform are toxic reagents that endanger health (Hansen et al., 2013).

Further, traditional methods, such as phenol isolation, isopropanol precipitation, formamide lysate method, nonorganic solvent isolation, and glass particle adsorption, are ineffective for isolating genomic DNA from a trace, dried, and frozen blood. Therefore, it is necessary to find a more convenient and efficient method for obtaining human genomic DNA (He et al., 2013). Saliva samples are a good alternative source of genomic DNA owing to the painless and noninvasive collection (Bux et al., 1995).

Compared to blood, saliva samples are much more 
convenient, efficient, and accessible if DNA can be isolated and purified.

A need for a reliable, easy to use, low cost, and not requiring special equipment DNA isolation method let us develop a DNA isolation kit for blood biological sample. The use of magnetic nanoparticles provides several advantages in biotechnological applications such as enzyme purifications, immunoassays, immunotherapy, and nucleic acid isolation (Borlido et al., 2013; Intorasoot et al., 2009)

Even though uncoated magnetic nanoparticles can bind to DNA and can be used for its isolation, polymer-coated magnetite nanoparticles provide a higher recovery of DNA. Magnetic nanoparticles are coated with different polymers such as agarose and silica (Taylor et al., 2000; Yoza et al., 2002; Chiang et al., 2005) previously described and used for bacterial cells. In this study, we compare three commercial DNA isolation kits with a gelatin-coated magnetic nanoparticles-based method to isolate blood biological samples.

\section{MATERIALS AND METHODS}

\section{Materials}

The following materials were used: gelatin-coated magnetic nanoparticle (GMNPs) genomic DNA isolation method called INBIOMag Genomic DNA Kit (INBIOMEDIC, Peru), QIAamp DNA Blood Mini Kit (Qiagen Cat. No. 51104); GeneJET Genomic DNA Purification Mini Kit (Thermo Scientific, Cat No. K0721) and MagJET Genomic DNA Kit (Thermo Scientific, Cat No. K2721). Oligonucleotide primers were synthesized by Macrogen Inc., Korea. All other chemicals and enzymes used were of high-grade purity.

\section{Sample Collection}

Peripheral venous blood samples were collected from 30 participants, who visited INBIOMEDIC Research and Technological Center. After obtaining written informed consent, $3 \mathrm{ml}$ of blood samples were collected in a tube containing ethylenediaminetetraacetic acid (EDTA) as an anticoagulant. Each sample was divided into $1 \mathrm{ml}$ aliquots and stored at $-20{ }^{\circ} \mathrm{C}$ until DNA isolation. DNA isolation from all samples was completed within 3 days after collected blood. The study protocol was approved by INMENSA Ethics Committee, Peru.

\section{DNA extraction methods}

The four methods are described:

A: Gelatin-coated magnetic nanoparticle genomic DNA isolation method (INBIOMag Genomic DNA Kit): 400 ul of whole blood was used and mix with $1.2 \mathrm{ml}$ of Red Blood Cell lysis (RBC) buffer by a vortex. The solution was incubated at room temperature for $2 \mathrm{~min}$ and centrifuge $13000 \mathrm{~g}$ for 1 min. Pellet was mixed with RBC buffer and centrifuge $13000 \mathrm{~g}$ for $1 \mathrm{~min}$. Pellet was mixed with $100 \mathrm{ul}$ of $\mathrm{NaCl}$ Solution and $40 \mathrm{ul}$ of Proteinase K, then it was added 600ul of cell lysis buffer and incubate to $56{ }^{\circ} \mathrm{C}$ for $10 \mathrm{~min}$. After incubation, 50ul of GMNPs $(50 \mathrm{mg} / \mathrm{ml})$ with 400 isopropanol and 400 ul of binding buffer $(1.25 \mathrm{M}$ sodium chloride and $10 \%$ polyethylene glycol 6000) were added to the lysate. The solution was mixed and incubated at room temperature for $10 \mathrm{~min}$. The magnetic pellet was immobilized in a magnetic rack and the supernatant was removed. The magnetic pellet was washed three times with wash buffer and dried for $15 \mathrm{~min}$. The magnetic pellet was then resuspended in $100 \mathrm{ul}$ of Tris-EDTA (TE) buffer and incubated at $65^{\circ} \mathrm{C}$ for 10 min. The supernatant containing the DNA and was transferred to a fresh tube.

B. QIAamp DNA Blood Mini Kit: 200 ul of the sample were incubated with $20 \mathrm{uL}$ of Proteinase $\mathrm{K}$ in $200 \mathrm{ul} \mathrm{Buffer} \mathrm{AL}$ for $10 \mathrm{~min}$ at $56^{\circ} \mathrm{C}$. 200ul of ethanol was then added. The remainder of the isolation procedure was carried out according to the manufacturer's protocol.

C. GeneJET Genomic DNA Purification Mini Kit: $200 \mathrm{ul}$ of the sample were incubated with $20 \mathrm{uL}$ of Proteinase K in 400 ul Lysis Solution for $10 \mathrm{~min}$ at $56^{\circ} \mathrm{C}$. 200ul of ethanol was then added. The remainder of the isolation procedure was carried out according to the manufacturer's protocol.

D. MagJET Genomic DNA Kit: 3 volumes of the sample was mixed with $1 \mathrm{X}$ RBC Buffer and incubated on ice for 4-7 minutes. The solution was centrifuge in cold at $7000 \mathrm{~g}$ for $5 \mathrm{~min}$. The supernatant was removed. The remainder of the extraction procedure was carried out according to the manufacturer's protocol.

The yield and quality of the DNA isolation methods were analyzed by QIAexpert. 


\section{Gel electrophoresis score}

To observe possible degradation due to the action of nucleases during the isolation procedure, $1 \mu \mathrm{g}$ of stock DNA from samples representative of each isolation method was electrophoresed on $1 \%$ agarose gel and visualized with blue light. A smeared band was indicative of sheared or degraded DNA samples.

\section{PCR amplification}

Genomic DNA isolation quality from whole blood was analyzed by PCR amplification of the BRCA- 1 gene. All PCRs were performed in a 50 ul reaction volume using Platinum Taq Polymerase (Invitrogen) according to the manufacturer's procedure and using the GTQ cycler 24 (Hain). BRCA-1 specific sequence $(242 \mathrm{bp})$ was amplified by primer pairs: BR1c68_69delF GAAGTTGTCATTTTATAAACCTTT-3') and BR1c68_69delR

$(5-$ GTATGTAAGGTCAATTCTGTTC-3') (Lee at al., 2016) using $100 \mathrm{ng}$ of DNA template. Thermal cycling was performed at $94{ }^{\circ} \mathrm{C}$ for $2 \mathrm{~min}$, followed by 35 cycles of $94{ }^{\circ} \mathrm{C}$ for $30 \mathrm{sec}, 45^{\circ} \mathrm{C}$ for $30 \mathrm{sec}, 72$ ${ }^{\circ} \mathrm{C}$ for $1 \mathrm{~min}$. PCR products were analyzed on $1.5 \%$ agarose gel electrophoresis and visualized with blue light.

\section{DNA sequencing}

PCR products obtained from genomic DNA extracted from whole blood, were purified and sent for sequencing (Macrogen) using the primers BR1c68_69delF and BR1c68_69delR.

\section{RESULTS}

\section{DNA concentration and yield}

The total concentration and yield of isolated DNA samples were estimated from spectrometric measurements using the QIAexpert platform. Summary statistics of 30 samples isolated using four methods are shown in Table 1. Method D extracted the most concentrated DNA with an average of 53.90 $\mathrm{ng} / \mu \mathrm{l}$, followed by method A with an average of 36.78 $\mathrm{ng} / \mu \mathrm{l}$, both are methodologies based on magnetic nanoparticles.

Method B and C showed a median value of 16.03 and $10 \mathrm{ng} / \mu \mathrm{l}$ respectively, both are methodologies based on silica columns. The total yield of isolated DNA from each sample was calculated by multiplying
DNA concentration with the final elution volume of $100 \mu$. All samples isolated using methods A and D had a total DNA yield above $2 \mathrm{ug}$ required for sequencing.

Table 1: Summary of total DNA yield and DNA concentration based on QIAexpert measurements obtained from the four extraction methods

\begin{tabular}{ccc}
\hline \multirow{2}{*}{$\begin{array}{c}\text { Isolate } \\
\text { method* }\end{array}$} & $\begin{array}{c}\text { Total DNA yield } \\
(\mu \mathrm{g}) \text { per } 100 \mu \mathrm{l}\end{array}$ & $\begin{array}{c}\text { DNA concentration } \\
(\mathrm{ng} / \mathrm{ul})\end{array}$ \\
\cline { 2 - 3 } & Mean & Mean \\
\hline $\mathrm{A}$ & 3.68 & 36.78 \\
$\mathrm{~B}$ & 1.60 & 16.03 \\
$\mathrm{C}$ & 1.00 & 10.00 \\
$\mathrm{D}$ & 5.39 & 53.90 \\
\hline
\end{tabular}

* 30 samples per isolation method

\section{DNA purity}

To assess DNA isolated purity by four different methods, absorbance was measured at 230, 260, and $280 \mathrm{~nm}$ wavelengths and the ratio of these absorbances were computed to estimate the relative purity of test samples. A260/A280 and A260/A230 ratios are summarized in Table 2. Methods A, B, and $\mathrm{D}$ isolated the purest DNA from 30 samples with a mean A260/A280 ratio of $1.62,1.70$, and 1.72, respectively. Method $\mathrm{C}$ had the lowest mean A260/A280 ratio of 0.94 .

The results of the A260/A230 ratio showed that methods $\mathrm{A}, \mathrm{C}$, and $\mathrm{D}$ had mean values $>1.0$ which was indicative of pure DNA free of organic contaminants (Table 2). Method B however, gave values lower than 1 , which suggested the presence of residual phenol or chaotropic salts that strongly absorb at $230 \mathrm{~nm}$.

Table 2 Summary of A260/A280 and A260/A230 ratios obtained from the four extraction methods

\begin{tabular}{ccc}
\hline \multirow{2}{*}{$\begin{array}{c}\text { Isolate } \\
\text { method* }\end{array}$} & A260/A280 & A260/A230 \\
\cline { 2 - 3 } & Mean & Mean \\
\hline $\mathrm{A}$ & 1.62 & 1.00 \\
$\mathrm{~B}$ & 1.70 & 0.94 \\
$\mathrm{C}$ & 0.94 & 1.13 \\
$\mathrm{D}$ & 1.72 & 1.33 \\
\hline
\end{tabular}

* 30 samples per extraction method 


\section{DNA integrity}

DNA integrity was checked by electrophoresis of stock DNA samples representative of four isolation methods, as shown in Figure 1. All four isolation methods were capable of isolating non-degraded, slow-migrating genomic DNA with high-molecularweight $>10 \mathrm{~kb}$. A method sample showed the least amount of shearing compared to $\mathrm{B}, \mathrm{C}$, and D methods samples.

\section{End-point assay: PCR}

BRCA-1 amplification by PCR was followed by the separation of PCR products on $1.5 \%$ agarose gel. As shown in Figure 2, the amplification pattern was consistent for all samples using method $\mathrm{A}$ and was further confirmed by direct sequencing.

\section{DNA sequencing}

Sanger sequencing was performed on 5 DNAs samples isolated by A method. The alignment in Figure 3 showed the successful detection of candidate mutations for each sample. The sequencing performance in the DNA isolated from the Gelatincoated magnetic nanoparticle genomic DNA method is optimal.

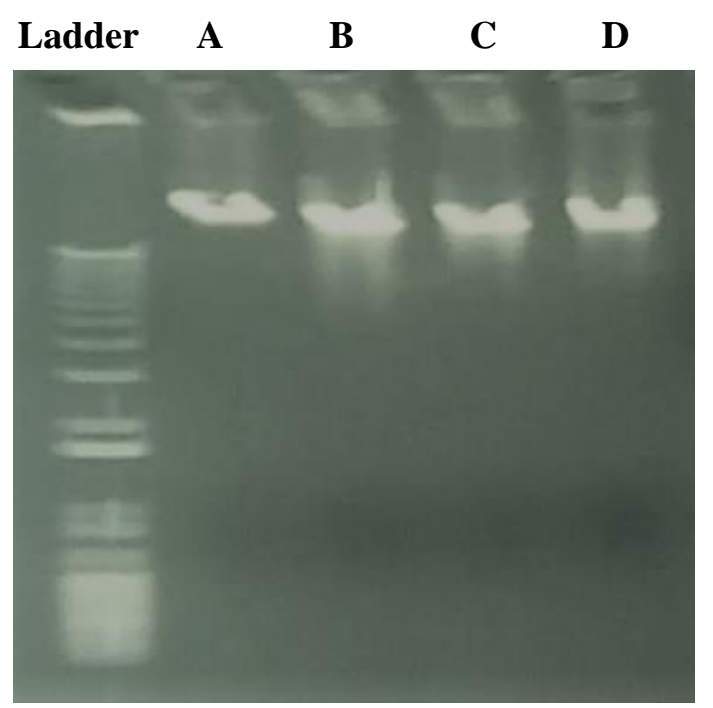

Figure 1 Gel electrophoresis analysis of genomic DNA samples isolated from human whole blood using four different methods. Method A (lane 1), method B (lane 2), method C (lane 3), and method D (lane 4). Molecular weight marker: $1 \mathrm{~kb}$ Plus DNA Ladder

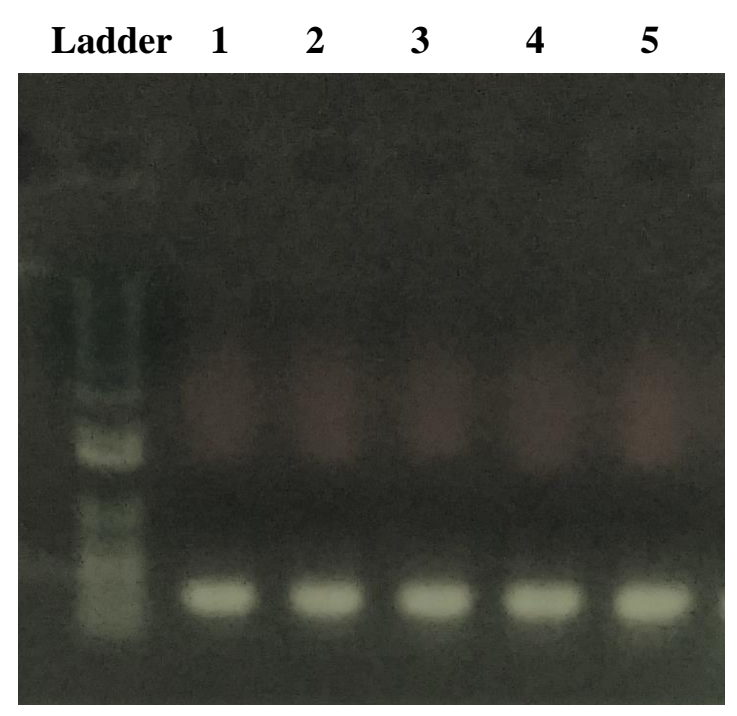

Figure 2 Gel electrophoresis analysis of PCR products isolated from human whole blood using method A in five samples. Molecular weight marker: $1 \mathrm{~kb}$ Plus DNA Ladder

\section{Assessment of time, cost, and labor intensity}

Other desirable factors considered for routine DNA isolation are the time involved, cost incurred, and the intensity of labor that the operator must put in. The fastest isolation protocol was the column-based method B followed by method C. Method A and D were the most time-consuming procedures. Relatively, method A was the cheapest since it did not require the use of complex equipment.

\section{CONCLUSION}

In summary, the gelatin-coated magnetite particles for genomic DNA isolation method (INBIOMag Genomic DNA Kit) developed in this study provide an efficient, simple, and inexpensive method that does not require the use of commercial DNA Isolation Kit.

\section{Acknowledgements}

This study was supported by Innovate Peru of Peruvian Production Ministry, number 404-RHAC2016.

\section{Conflicts of interest}

The authors declare no conflicts of interest. 


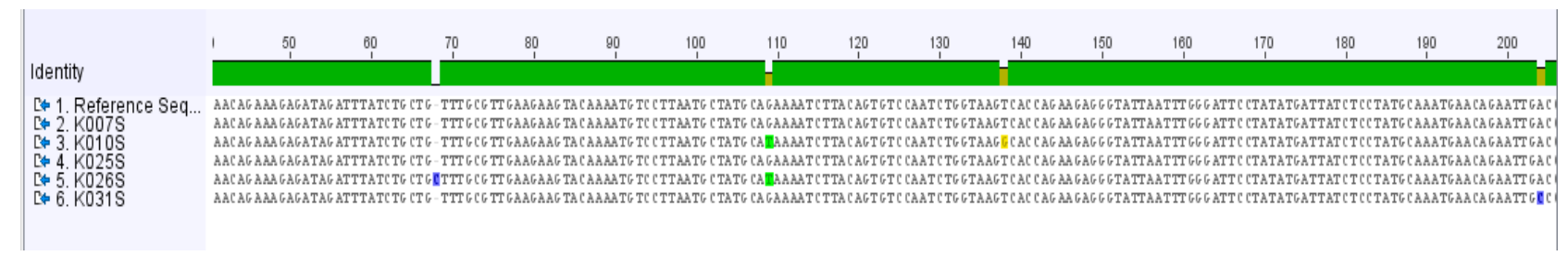

Figure 3 Sanger sequencing for the BRCA-1 gene (242bp) alignment analysis using Geneious 4.8.4.

\section{REFERENCES}

Borlido L, Azevedo AM, Roque ACA, Aires-Barros MR. 2013. Magnetic separations in biotechnology, Biotechnol. Adv; 31:1374-1385.

Bux J, Stein EL, Santoso S, et al. 1995. NA gene frequencies in the German population, determined by polymerase chain reaction with sequence-specific primers. Transfusion; 35(1):54-57.

Chiang CL, Sung CS, Wu TF, Chen CY, Hsu CY. 2005. Application of superparamagnetic nanoparticles in purification of plasmid DNA from bacterial cells, $\mathrm{J}$. Chromatogr. B Anal. Technol. Biomed. Life Sci; 822:54-60.

Cho YK, Lee JG, Park JM, Lee BS, Lee Y, Ko C. 2007. One-step pathogen specific DNA extraction from whole blood on a centrifugal microfluidic device. Lab Chip; 7:565-573.

Hansen WL, Bruggeman CA, Wolffs PF. 2013. Preanalytical sample treatment and DNA extraction protocols for the detection of bacterial pathogens from whole blood. Methods Mol Biol; 943:81-90.

He N, Wang F, Ma C, et al. 2013. Chemiluminescence analysis for HBV-DNA hybridization detection with magnetic nanoparticles based DNA extraction from positive whole blood samples. J Biomed Nanotechnol; 9:267-273.

Intorasoot $\mathrm{S}, \quad$ Srirung $\mathrm{R}$, Intorasoot $\mathrm{A}$, Ngamratanapaiboon S. 2009. Application of gelatincoated magnetic particles for isolation of genomic
DNA from bacterial cells, Anal. Biochem; 386:291292.

Lee SH, Zhou S, Zhou T, Hong G. 2016. Sanger Sequencing for BRCA1 c.68_69del, BRCA1 c.5266dup and BRCA2 c.5946del Mutation Screen on Pap Smear Cytology Samples. International Journal of Molecular Sciences; 17:229.

Taylor JI, Hurst CD, Davies MJ, Sachsinger N, Bruce IJ. 2000. Application of magnetite and silicamagnetite composites to the isolation of genomic DNA, J. Chromatogr. A; 890:159-166.

Yoza B, Matsumoto M, Matsunaga T. 2002. DNA extraction using modified bacterial magnetic particles in the presence of amino silane compound, $\mathrm{J}$. Biotechnol; 94:217-224. 